\title{
Improving Thematic Learning Outcomes Using Problem Based Learning Models in Class III SD
}

\author{
Rohayati \\ SD Negeri Ketanggan 02 \\ rohay11@gmail.com
}

\section{Article History}

received 3/12/2020

revised 17/12/2020

accepted 31/12/2020

\begin{abstract}
This study aims to improve thematic learning outcomes by using the Problem Based Learning (PBL) model in class III SD Negeri Ketangan 02. In this study applying the type of classroom action research (CAR) using qualitative and quantitative approaches. The research subjects were third grade students of SD Negeri Ketangan 02 semester 2 for the 2019/2020 academic year with a total of 16 students. This research was conducted in two cycles. The results of the first cycle research on RPP an average of $81,48 \%(B)$, increased in the second cycle to $92.59 \%$ $(S B)$, the implementation of the first cycle on teacher activities an average of $82.50 \%$ (B) increased in the second cycle to $95.00 \%$ (SB), the implementation of the first cycle on student activity an average of $82.50 \%$ (B) increased in the second cycle to $95.00 \%$ (SB). Student learning outcomes in the first cycle averaged $78(C)$, increased in the second cycle to 93 (SB). So it can be concluded that learning by applying the Problem Based Learning model is able to improve student learning outcomes in class III teamtic learning at SD Negeri Ketangan 02.
\end{abstract}

Keywords: learning outcomes, problem based learning, thematic

\begin{abstract}
Abstrak
Penelitian ini bertujuan untuk meningkatkan hasil belajar tematik dengan menggunakan model Problem Based Learning (PBL) di kelas III SD Negeri Ketanggan 02. Pada penelitian ini menerapkan jenis penelitian tindakan kelas (PTK) menggunakan pendekatan kualitatif dan kuantitatif. Subjek penelitian adalah siswa kelas III SD Negeri Ketangan 02 semester 2 tahun pelajaran 2019/2020 dengan jumlah siswa 16 orang. Penelitian ini dilakukan dalam dua siklus. Hasil penelitian siklus I pada RPP rata-rata $81,48 \%$ (B), meningkat pada siklus II menjadi $92,59 \%$ (SB), Pelaksanaan siklus I pada Aktivitas guru rata-rata $82,50 \%$ (B) meningkat pada siklus II menjadi 95,00\% (SB), Pelaksanaan siklus I pada Aktivitas siswa rata-rata $82,50 \%$ (B) meningkat pada siklus II menjadi $95,00 \%$ (SB). Hasil belajar siswa pada siklus I rata-rata 78 (C), meningkat pada siklus II menjadi 93 (SB). Sehingga dapat disimpulkan bahwa pembelajaran dengan menerapkan model Problem Based Learning mampu meningkatkan hasil belajar siswa pada pembelajaran teamtik kelas III SD Negeri Ketangan 02.
\end{abstract}

Kata kunci: hasil belajar, pembelajaran berbasis masalah, tematik

Social, Humanities, and Education Studies (SHEs): Conference Series https://jurnal.uns.ac.id/shes

p-ISSN 2620-9284

e-ISSN 2620-9292 


\section{PENDAHULUAN}

Pembelajaran merupakan suatu bantuan yang diberikan oleh guru kepada peserta didik di lingkungan belajar dengan tujuan agar peserta didik mendapatkan ilmu pengetahuan, sikap maupun ketrampilan (Anggarayanthi, Suniasih, \& Suara, 2016). Permendikbud No. 22 Tahun 2016 menyatakan bahwa proses pembelajaran pada satuan pendidikan diselenggarakan secara interaktif, inspiratif, menyenangkan, menantang, memotivasi siswa untuk berpatisipasi aktif serta memberikan ruang yang cukup bagi prakarsa, kreativitas dan kemandirian sesuai dengan bakat, minat dan perkembangan fisik serta psikologis siswa. Hal ini sejalan dengan Anugraheni (2017:248) agar proses pembelajaran dapat membantu serta memfasilitasi pengembangan potensi siswa, maka diperlukan proses pembelajaran yang mengarah pada penekanan aktivitas siswa dan pergeseran tanggung jawab belajar kearah siswa sehingga siswa dapat mengembangkan potensi yang dimiliki. Untuk itu setiap satuan pendidikan melakukan perencanaan pembelajaran, pelaksanaan proses pembelajaran serta penilaian proses pembelajaran untuk meningkatkan efisiensi dan efektivitas ketercapaian kompetensi lulusan, dengan demikian tujuan pembelajaran akan tercapai. Salah satu pembelajaran yang digunakan adalah pembelajaran tematik terpadu.

Orientasi kurikulum 2013 adalah terjadinya peningkatan dan keseimbangan antara kompetensi sikap, keterampilan dan pengetahuan pada peserta didik. (Masjid, 2014). Pendekatan pembelajaran yang digunakan pada kurikulum 2013 adalah pembelajaran tematik terpadu.

Pembelajaran tematik adalah pembelajaran yang terjaring dalam satu tema, pembelajaran tematik menggunakan tema untuk mengaitkan beberapa mata pelajaran sehingga dapat memberikan pengalaman bermakna kepada peserta didik (dalam jurnal Yalvema Miaz, 2019).

Pembelajaran tematik terpadu berfungsi untuk memberikan kemudahan bagi siswa dalam memahami dan mendalami konsep materi yang tergabung dalam tema, dapat menambah semangat belajar karena materi yang dipelajari merupakan materi yang nyata (kontekstual) dan bermakna bagi siswa. Dalam pembelajaran tematik terpadu, tema berperan sebagai pemersatu kegiataqan pembelajaran dengan memadukan beberapa muatan pelajaran sekaligus (Mustamilah, 2015).

Pelaksanaan pembelajaran tematik terpadu di Sekolah Dasar Kurikulum 2013 dilaksanakan dari kelas I sampai kelas VI. Hal ini dipertegas oleh peraturan Menteri Pendidikan dan Kebudayaan Nomor 67 tahun 2013 tentang kerangka dasar dan standar kurikulum Sekolah Dasar yang menyebutkan bahwa "Pelaksanaan Kurikulum 2013 pada Sekolah Dasar dilakukan melalui pembelajaran dengan pendekatan tematik terpadu dari kelas I sampai kelas VI.

Pembelajaran yang dapat membuat siswa aktif menuntut guru untuk dapat memiliki kemampuan dalam menyusun dan melaksanakan pembelajaran tematik terpadu yang menarik. Tujuannya agar tercipta pembelajaran tematik terpadu yang dapat membuat siswa aktif dalam membangun pengetahuan sendiri, memecahan masalah, mampu berpikir kritis dan bermakna bagi siswa (Marsali, 2016)

Pembelajaran tematik terpadu menuntut guru memiliki kemampuan dalam mengaitkan materi antar muatan pelajaran. Selain itu, guru juga harus mampu memahami berbagai macam model pembelajaran inovatif untuk diterapkan dalam pembelajaran agar siswa bersemangat mengikuti kegiatan belajar mengajar serta pembelajaran menjadi menyenangkan dan bermakna bagi siswa. Seperti yang dijelaskan Trianto (2015:57) " pembelajaran tematik terpadu sebagai suatu konsep dapat dikatakan sebagai suatu pendekatan belajar mengajar yang melibatkan beberapa bidang studi untuk memberikan pengalaman bermakna kepada anak didik."

Berdasarkan observasi yang peneliti lakukan dikelas III SD Negeri Ketanggan 02 pada tanggan 11 - 13 Mei 2020 pada tema 8 Praja Muda Karana subtema 3 Aku Suka Bertualang. Ditemukan permasalahan pada pembelajaran yaitu rendahnya hasil 
belajar siswa baik dari segi guru maupun segi peserta didik. Permasalahan dari segi guru adalah guru kurang mevariasikan metode, guru belum menghadapkan siswa pada maalah dunia nyata, guru kurang memberikan pertanyaan-pertanyaan yang bisa melatih daya pikir siswa, guru kurang memupuk kemampuan siswa untuk memecahkan susatu masalah nyata yang ada di sekitarnya, kurangnya kesempatan yang diberikan kepada siswa dalam mengungkapkan pendapat, kurangnya penggunaan media sebagai alat bantu agar siswa dapat lebih memahami materi yang diajarkan, pembelajaran masih berpusat pada guru.

Hasil belajar merupakan salah satu indikator pembelajaran yang digunakan guru untuk dijadikan ukuran atau kriteria dalam mencapai tujuan pembelajaran. Artinya setelah proses pembelajaran berlangsung diharapkan terjadi perubahan tingkah laku baik dari aspek sikap, pengetahuan dan keterampilan. Hal tersebut didukung oleh pendapat Trianto (2014:260) mengemukakan bahwa "hasil belajar tersebut pada hakikatnya mencakup aspek sikap, pengetahuan, keterampilan, dan nilai-nilai yang diwujudkan dalam kebiasaan berpikir dan bertindak, kompetensi ini dapat dikenali melalui sejumlah hasil belajar dan indikatornya dapat diukur dan diamati."

Permasalahan yang telah dipaparkan di atas terlihat bahwa kelas III SD Negeri Ketanggan 02 membutuhkan suatu tindakan untuk meningkatkan hasil belajar siswa dalam pembelajaran tematik. Untuk itu upaya untuk mengatasi permasalahan diatas dapat dilakukan guru untuk meningkatkan hasil belajar siswa adalah dengan menggunakan pembelajaran model Problem Based Learning (PBL). Menurut Sani (2019:149) "Problem Based Learning (PBL) merupakan pembelajaran yang penyampaiannya dilakukan dengan cara menyajikan suatu permasalahan, mengajukan pertanyaan-pertanyaan, memfasilitasi penyelidikan dan membuka dialog." Permasalahan yang dikaji merupakan permasalahan kontekstual yang ditemukan siswa dalam kehidupan sehari-hari.

Menurut Kemndikbud (2014:25) "pembelajaran berbasis masalah (problem based learning) merupakan sebuah pendektan pembelajaran yang menyajikan masalah konstektual sehingga merangsang peserta didik untuk belajar dimana peserta didik bekerja dalam tim untuk menyelesaikan masalah dunia nyata (real world)."

Model Problem Based Learning (PBL) bertujuan untuk membantu siswa agar memperoleh berbagai pengalaman dan mampu mengubah tingkah laku meiputi pengetahuan, ketrampilan, dan nilai norma terhadap perilkau siswa.

Dalam pelaksanaanya denga mengunakan model Problem Based Learning (PBL) diharapkan dangat membantu siswa dalam memahami materi pelajaran karena dalam proses pembelajaranya siswa dituntun secara aktif. Siswa dihadapkan pada masalah dunia nyata dan nantinya siswa diharapkan menemukan masalah, mendiskusikan masalah tersebut dan menyelesaikan masalah yang ada di sekitar siswa secara mandiri. Menurut Warsono dan Hariyanto (2014) kelebihan model PBL adalah :1) siswa akan terbiasa menghadapi masalah dan tertantang untuk menyelesaikan masalah yang tidak hanya terkait dengan pembelajaran di kelas tetapi juga menghadapi masalah yang ada dalam kehidupan sehari-hari (real world), 2) memupuk solidaritas sosial dengan terbiasa berdiskusi dengan teman-teman, 3) makin mengakrabkan guru dengan siswa, 4) membiasakan siswa melakukan eksperimen.

Pelaksanaan pembelajaran tematik dengan model Problem Based Learning berdasarkan langkah-langkah menurut (Sani:2019) yaitu :1) mengorientasikan siswa pada masalah, 2) mengorganisasikan siswa untuk belajar, 3) pelaksanaan investigasi, 4) mengembangkan dan menyajikan hasil kerja, 5) menganalisis dan mengevaluasi hasil pemecahan masalah.

Berdasarkan Permasalahan seperti di atas harus diatasi secara ilmiah melalui penelitian tindakan kelas dengan judul "Peningkatan Hasil Belajar Tematik menggunakan model Problem Based Learning di Kelas III SD". 


\section{METODE}

Penelitian ini adalah Penelitian Tindakan kelas (PTK) yang menggunakan pendekatan kualitatif dan kuantitatif. Penelitian ini dilaksanakan pada semester II tahun ajaran 2019/2020. Terdiri dari II siklus yaitu: siklus I pertemuan I dilaksanakan pada tanggal 11 Mei 2020 siklus I pertemuan II tanggal 11 Mei 2020 dan siklus II dilaksanakana pada tanggal 13 Mei 2020. Penelitian ini dilaksanakan di kelas III SD Negeri Ketanggan 02 Kecamatan Gringsing Kabupaten Batang.

Subjek penelitian ini adalah peserta didik kelas III SD Negeri Ketanggan 02 yang berjumlah 16 orang yang terdiri dari 6 orang peserta didik laki-laki dan 10 orang peserta didik perempuan. Selain itu, adapun yang terlibat dalam penilitian ini adalah peneliti sebagai praktisi, guru kelas sebagai observer .

Alur penelitian tindakan kelas ini dilaksanakan menggunakan model modifikasi siklus yang dikembangkan oleh Arikunto $(2015,144)$ yang mempunyai 4 tahap yaitu perencanaan, tindakan, pengamatan, dan refleksi. Penelitian tersebut dilaksanakan dengan 2 siklus, pada siklus I terdiri dari 2x pertemuan dan siklus II terdiri dari $1 \mathrm{x}$ pertemuan.

Sumber data berasal dari hasil pembelajaran yang dilakukan menggunakan model Problem Based Learning (PBL) dalam meningkatkan hasil belajar pada pembelajaran tematik di SD Negeri Ketanggan 02. Sumber data meliputi rencana pelaksanaan pembelajaran, pelaksanaan pembelajaran, dan penilaian terhadap semua aspek perilaku dan kegiatan guru dan siswa selama kegiatan pembelajaran. Data diperoleh dari subjek terteliti yakni guru dan siswa kelas.

Instrumen yang digunakan dalam penelitian ini antara lain: lembar penilaian RPP, lembar observasi dan lembar tes non tes. Teknik pengumpulan data melalui observasi yaitu berupa lembar tes dan non tes.

Analisis data merupakan proses penyusunan dan penganalisisan data-data yang diperoleh sehingga dapat ditarik kesimpulan dari penelitian yang dilakukan berdasarkan dari berbagai instrumen data tersebut. tahap analisis data yaitu: mereduksi data berati merangkum, setelah data direduksi, dan langkah selanjutnya adalah penarikan kesimpulan.

\section{HASIL DAN PEMBAHASAN}

\section{Hasil Penelitian}

Pelaksanaa penelitian tindakan kelas dibagi atas 2 siklus, dimana siklus I dua kali pertemuan dan siklus II satu kali pertemuan

\section{Perencanaan Siklus I}

Perencanaan pembelajaran tematik terpadu dengan menggunakan model Problem Based Learning (PBL) disusun dalam bentuk RPP (Rencana Pelaksanaan Pembelajaran). Perencanaan yang dilakukan berdasarkan program akademik semester II sesuai dengan waktu penelitian yang dilaksanakan. Perencanaan disusun untuk pertemuan pertama pada siklus I pertemuan 1 yaitu $6 \times 35$ menit. Sebelum RPP disusun, peneliti dan guru kelas terlebih dahulu menganalisis antara tema, subtema dan pembelajaran yang dikembangkan berdasarkan Kurikulum 2013. Peneliti memilih tema 8 Praja Muda karana subtema 3 Aku Suka Bertualang pembelajaran 1.

Rencana Pelaksanaan Pembelajaran yang dilaksanakan terdiri dari Kompetensi Inti (KI), Kompetensi Dasar (KD), indikator, tujuan pembelajaran, materi pokok, materi pembelajaran, model, pendekatan dan metode pembelajaran, kegiatan pembelajaran, media, alat dan sumber belajar, serta penilaian.

Penilaian terhadap RPP dilaksanakan melalui lembar penilaian RPP dengan aspek penilaian yang terdiri dari (a) Kejelasan perumusan tujuan proses pembelajaran, (b) Pemilihan materi ajar, (c) Pengorganisasian materi ajar, (d) Pemilihan sumber atau 
materi pembelajaran, (e) Menyusun langkah-langkah pembelajaran sesuai dengan PBL, (f) Teknik pembelajaran, (g) dan Kelengkapan instrumen . Berdasarkan hasil penilaian yang dilakukan oleh observer,Jadi, persentase skor yang diperoleh praktisi (peneliti) pada penilaian RPP siklus I pertemuan I adalah $77,78 \%$ dengan kualifikasi baik (B).

\section{Pelaksanaan Siklus I}

Pelaksanaan pembelajaran pada siklus I pertemuan 1 dengan model Problem Based Learning (PBL) dilaksanakan dikelas III SD Negeri Ketanggan 02. Pertemuan pertama dilaksanakan pada hari Kamis tanggal 11 Mei 2020 mulai pukul 08.00 sampai 12.30 WIB. Tema yang diajarkan pada siklus 1 pertemuan 1 adalah tema 8 Praja Muda Karana Subtema 3 Aku Suka Bertualang Pembelajaran 1. Muatan pelajaran yang terkait pada pembelajaran ini adalah Bahasa Indonesia, PPKn dan Matematika. Dalam pelaksanaan, peneliti berperan sebagai praktisi (guru) dan guru kelas III sebagai observer yang mengamati jalannya pembelajaran tematik terpadu dengan model Problem Based Learning (PBL).

Pelaksanaan tindakan dibagi menjadi tiga tahap yaitu kegiatan pendahuluan, kegiatan inti, dan kegiatan akhir sesuai dengan yang telah disusun dalam RPP.

\section{Pengamatan Siklus I}

Pengamatan dilakukan terhadap hasil penyusunan RPP, aktivitas guru dan peserta didik. Penilaian pada RPP pada siklus I yaitu dengan rata-rata $81,48 \%$ (baik). sedangkan untuk aktivitas guru adalah dengan rata-rata $82,50 \%$ (baik), dan untuk aktivitas siswa dengan rata-rata $82,50 \%$ (baik).

\section{Hasil Belajar}

Pada siklus I pertemuan 1, hasil belajar siswa diperoleh rata-rata 74. Kemudian pada siklus I pertemuan 2 hasil belajar siswa diperoleh rata-rata 82. Dengan demikian hasil belajar siswa siklus I memperoleh rata-rata 78 (cukup).

\section{Refleksi}

Berdasarkan hasil observasi dan tes yang telah dilakukan maka dapat disimpulkan bahwa hasil belajar siswa pada siklus I menunjukkan bahwa secara keseluruhan pembelajaran belum mencapai hasil maksimal sebagaimana yang diharapkan. Oleh karena itu, perlu dilakukan perbaikan dalam perencanaan dan pelaksanaan dalam pembelajaran untuk mencapai proses dan hasil belajar yang maksimal. Segala kekurangan yang ditemui pada siklus I akan diperbaiki pada siklus II.

\section{Perencanaan Siklus II}

Pada tahap ini peneliti membuat persiapan untuk pelaksanaan tindakan pada siklus II. Persiapan tersebut disusun dan diwujudkan dalam bentuk Rencana Pelaksanaan Pembelajaran (RPP).Peneliti memilih tema 8 Praja Muda Karana subtema 3 Aku Suka Bertualang pembelajaran 1. Siklus II disajikan dalam waktu 1 kali pertemuan yaitu pada hari Selasa tanggal 12 Mei 2020 mulai pukul 08.00 sampai 12.30. Perencanaan yang dilakukan berdasarkan program semester II sesuai dengan waktu penelitian berlangsung.

Penilaian terhadap RPP dilaksanakan melalui lembar penilaian RPP dengan aspek penilaian yang terdiri dari (a) Kejelasan perumusan tujuan proses pembelajaran, (b) Pemilihan materi ajar, (c) Pengorganisasian materi ajar, (d) Pemilihan sumber atau materi pembelajaran, (e) Menyusun langkah-langkah pembelajaran sesuai dengan PBL, (f) Teknik pembelajaran, (g) dan Kelengkapan instrumen. Berdasarkan hasil penilaian yang dilakukan oleh observer Jadi, persentase skor yang diperoleh praktisi (peneliti) pada penilaian RPP siklus II adalah 92,59\% dengan kualifikasi sangat baik (SB/A) .

\section{Pelaksanaan Siklus II}

Pelaksanaan pada siklus II penelitian ini disesuaikan dengan model Problem Based Learning (PBL) sesuai dengan langkah yang dikemukakan Hosnan (2014:302) menjelaskan bahwa "Langkah-langkah pembelajaran Problem Based Learning (PBL) 
yaitu: 1) Mengorientasikan peserta didik terhadap masalah. 2) Mengorganisasi peserta didik untuk belajar. 3)Membimbing penyelidikan individual atau kelompok. 4) Mengembangkan dan menyajikan hasil karya. 5) Menganalisis dan mengevaluasi proses pemecahan masalah.

\section{Pengamatan Siklus II}

Pengamatan dilakukan terhadap hasil penyusunan RPP, aktivitas guru dan peserta didik. Penilaian pada RPP pada siklus II yaitu $92,59 \%$ dengan kualifikasi sangat baik (SB/A). Aspek guru pada siklus II diperoleh skor 95,00\% dengan kualifikasi sangat baik (SB/A). Aspek peserta didik siklus II memperoleh skor 95,00\% dengan kualifikasi sangat baik (SB/A).

Hasil Belajar

Hasil belajar siswa pada siklus II mencakup aspek pengetahuan, dan keterampilan, dengan rata-rata kelas 93,13 dengan kualifikasi sangat baik (SB). Jumlah siswa yang tuntas yaitu sebanyak 15 orang dan yang tidak tuntas sebanyak 1 orang. Dapat disimpulkan bahwa siklus II sudah sangat baik dan telah mencapai ketuntasan belajar minimal 75 . Untuk itu tidak perlu diadakan tindak lanjut dan penelitian dapat diakhiri pada siklus II ini.

\section{Refleksi}

Berdasarkan hasil observasi dan tes yang telah dilakukan maka proses dan hasil belajar siswa pada siklus II ini menunjukkan bahwa secara keseluruhan pembelajaran sudah meningkat. Dengan demikian, dapat disimpulkan bahwa penelitian dalam pembelajaran siklus II telah terlaksanakan dengan sangat baik dan telah berhasil.

\section{Pembahasan}

\section{Perencanaan siklus I}

Pelaksanaan pembelajaran tematik terpadu dilaksanakan sesuai dengan rencana yang telah ditetapkan. Dalam pelaksanaan pembelajaran, peneliti beracuan kepada perencanaan yang tertuang dalam bentuk RPP. Pada perencanaan siklus I pertemuan 1 masih banyak terdapat kekurangan diantaranya pemilihan materi ajar belum sesuai dengan karakteristik siswa dan belum sesuai dengan yang diajarkan. Pengorganisasian materi ajar belum sistematis. Permasalahan lain yang ditemukan adalah pemilihan sumber atau materi ajar belum sesuai dengan karakteristik siswa, dan belum sesuai dengan lingkungan siswa. Selain itu kekurangan yang ditemui yaitu teknik pembelajaran belum sesuai dengan karakteristik siswa dan belum sesuai dengan lingkungan sekolah. Kekurangan selanjutnya yaitu cakupan materi belum luas. Pembahasan tindakan terhadap pelaksanaan pembelajaran tematik terpadu untuk meningkatkan hasil belajar siswa menggunakan model Problem Based Learning siklus I meliputi: (1) pendahuluan; (2) inti dan (3) penutup.

Berdasarkan hasil penelitian dan analisis data pada lembar pengamatan RPP yang diisi oleh obsever (guru kelas) pada siklus I pertemuan 1 diketahui bahwa persentase perencanaan (RPP) adalah $77,78 \%$ dengan kualifikasi $B$ (Baik), sedangkan pada siklus 1 pertemuan 2 diketahui bahwa persentase perencanaan (RPP) adalah $85,19 \%$ dengan kualifikasi B (Baik). Pada siklus I ini rata-rata persentase perencanaan (RPP) adalah 81,48\% dengan kualifikasi B (Baik). Maka dari itu peneliti harus membuat RPP dengan komponen yang lengkap sesuai prosedur supaya tujuan pembelajaran yang diharapkan dapat tercapai dengan maksimal. Hal ini sesuai dengan teori yang diungkapkan oleh Daryanto (2014:87) "Rencana Pelaksanaan Pembelajaran (RPP) pada dasarnya merupakan suatu bentuk prosedur dan manajemen pembelajaran untuk mencapai kompetensi dasar yang telah ditetapkan dalam standar isi (standar kurikulum )". 


\section{Pelaksanaan siklus I}

Pelaksanaan Berdasarkan lembar pengamatan aktivitas guru dalam pembelajaran tematik terpadu untuk meningkatkan hasil belajar siswa, beberapa tahap pembelajaran yang belum terlaksana dengan baik. Pelaksanaan pembelajaran pada siklus I pertemuan 1 menunjukkan bahwa belum seluruh siswa memahami proses pembelajaran dengan model PBL. Berdasarkan lembar observasi dan diskusi antara peneliti dan observer, penyebab dari belum tercapainya proses pembelajaran yang diharapkan pada siklus I pertemuan 1 ini secara garis besar adalah siswa belum bisa memprediksi masalah yang akan dipelajari, belum aktif dalam proses pembelajaran, dan belum aktif mencari informasi yang berhubungan dengan masalah, hal ini karena peneliti belum maksimal dalam melaksanakan proses pembelajaran.

Jadi, peneliti harus lebih merencanakan proses pembelajaran agar lebih terlaksana dengan maksimal sampai dengan kegiatan evaluasi. Hal ini sesuai dengan yang diungkapkan oleh Suryosubroto (2002:71) tujuan proses pembelajaran adalah "Dapat mengembangkan cara belajar peserta didik untuk mendapatkan, mengelola, menggunakan dan mengkomunikasikan apa yang telah diperoleh dalam proses belajar tersebut".

Pada tahap pelaksanaan rata-rata persentase keberhasilan aktivitas guru pada siklus I pertemuan 1 memperoleh $80,00 \%$ dengan kualifikasi baik (B). Dengan demikian proses pembelajaran dilanjutkan ke siklus I pertemuan 2. Pada tahap pelaksanaan rata-rata persentase keberhasilan aktivitas guru pada siklus I pertemuan 2 memperoleh $85,00 \%$ dengan kualifikasi baik (B). Maka pada siklus I didapat rata-rata persentasi keberhasilan guru adalah $82,50 \%$ baik (B). Sedangkan pada tahap pelaksanaan aktivitas siswa pada siklus I pertemuan 1 memperoleh $80,00 \%$ dengan kualifikasi baik (B). Dengan demikian dilanjutkan pada siklus I pertemuan 2 memperoleh $85,00 \%$ dengan kualifikasi cukup (B). Maka pada siklus I didapat rata-rata persentasi keberhasilan siswa adalah $82,50 \%$ dengan kualifikasi baik (B). Kekurangan pada pelaksanaan siklus I ini harus diperbaiki pada siklus selanjutnya.

\section{Hasil Belajar Siklus I}

Pencapaian hasil penilaian peningkatan hasil belajar siswa pada pembelajaran tematik terpadu dengan menggunakan model Problem Based Learning ( $P B L$ ) yang dilakukan guru meliputi tiga aspek yaitu aspek sikap, pengetahuan, dan keterampilan. Aspek pengetahuan dan keterampilan dengan memperoleh rata-rata kelas yaitu 73,75 dengan kualifikasi kurang (D). Hasil penilaian peningkatan hasil belajar pada siklus I pertemuan 1 belum tercapai sehingga pelaksanaan harus dilanjutkan ke siklus I pertemuan 2. Pada siklus I pertemuan 2 diperoleh rata-rata 81,82 dengan kualifikasi cukup (C) sehingga didapat rata-rata 77,81 (C).

Namun, berdasarkan kolaborasi peneliti dengan guru kelas sebagai observer disimpulkan pembelajaran pada siklus belum tuntas karena belum mencapai target yang peneliti dan observer tetapkan yaitu $75 \%$ peserta didik yang tuntas. Untuk memperbaiki kekurangan yang terjadi pada Siklus I peneliti melanjutkan ke Siklus II, sebagai perbadingan apakah model PBL (Problem Based Learning) dapat meningkatkan hasil belajar peserta didik.

Tabel 1. Hasil Pengamatan RPP, Aspek Guru, Aspek Siswa Siklus I Pertemuan I dan II

\begin{tabular}{llccc}
\hline \multirow{2}{*}{ No } & \multirow{2}{*}{ Hasil Pengamatan } & \multicolumn{2}{c}{ Siklus I } & \multirow{2}{*}{ Rata-rata } \\
\cline { 3 - 4 } & & I & II & \\
\hline 1. & RPP & 77,78 & 85,19 & 81,48 \\
2. & Aspek guru & 80,00 & 85,00 & 82,50 \\
3. & Aspek siswa & 80,00 & 85,00 & 82,50 \\
4. & Hasil belajar & 73,75 & 81,82 & 78 \\
\hline
\end{tabular}




\section{Refleksi}

Berdasarkan pengamatan perencanaan, pelaksanaan pembelajaran dari aktivitas guru dan siswa serta hasil belajar siswa siklus I masih terdapat kekurangan. Jadi penerapan model Problem Based Learning pada proses pembelajaran tematik terpadu masih belum terlaksana dengan maksimal. Dengan demikian, penelitian pembelajaran dengan model Problem Based Learning dilanjutkan ke siklus II.

\section{Perencanaan Siklus II}

Perencanaan pada siklus II tidak jauh berbeda dengan perencanaan pembelajaran pada siklus I pertemuan 1 dan 2. Perencanaan pada siklus I sudah terlaksana dengan kualifikasi baik. Perencanaan pembelajaran pada siklus II ini mengalami peningkatan dibandingkan dengan pada siklus sebelumnya.

Berdasarkan rekapitulasi data yang dilakukan oleh observer pada lembaran pengamatan RPP diketahui bahwa perolehan persentase skor pada siklus II adalah $92,59 \%$ dengan kualifikasi sangat baik. Dari pemaparan data yang disajikan di atas, dapat disimpulkan bahwa perencanaan pembelajaran tematik dengan menggunakan model PBL di kelas III SD Negeri Ketanggan 02 telah terlaksana dengan kriteria sangat baik pada siklus II. Terdapat korelasi antara peningkatan dalam perencanaan terhadap hasil belajar siswa pada pembelajaran tematik dengan menggunakan model PBL. Pada siklus II RPP telah dirancang dan dilaksanakan dengan sangat baik untuk mencapai proses pembelajaran yang maksimal. Menurut Muslich (2011:53) "Secara teknis rencana pembelajaran mencakup komponen-komponen berikut (1) kejelasan perumusan tujuan proses pembelajaran, (2) pemilihan materi ajar, (3) pengorganisasian materi ajar, (4) pemilihan sumber atau materi pembelajaran, (5) menyusun langkah-langkah pembelajaran sesuai dengan PBL, (6) teknik pembelajaran, (7) dan kelengkapan instrumen. Pada siklus II ini peneliti telah membuat RPP sesuai dengan komponen-komponen yang lengkap seperti penjelasan diatas.

\section{Pelaksanaan Siklus II}

Berdasarkan penelitian dengan model Problem Based Learning (PBL) pada siklus II pada pelaksanaan pembelajaran telah membuat siswa aktif dalam belajar, siswa mampu memecahkan masalah dan memahami materi yang diajarkan dengan baik.

Berdasarkan hasil penilaian observer terhadap aktivitas guru dan siswa pada siklus II, diperoleh presentase skor 95,00\% pada aktivitas guru dan 95,00\% pada aktivitas siswa.

Berdasarkan hal tersebut dapat disimpulkan bahwa pelaksanaan pembelajaran dengan model PBL pada siklus II sudah terlaksana sesuai dengan yang diharapkan.

\section{Hasil Belajar}

Hasil belajar siswa pada siklus II mengalami peningkatan. Dilihat dari aspek sikap sudah tidak ada lagi siswa yang melakukan hal-hal yang bertentangan dengan hal negatif. Aspek pengetahuan dan aspek keterampilan 93.

Berdasarkan data diatas, terlihat bahwa hasil belajar siswa pada pembelajaran tematik terpadu dengan menggunakan model Problem Based Learning (PBL) di kelas III SD Negeri Ketanggan 02 mengalami peningkatan. Pada siklus II hasil belajar siswa diperoleh nilai rata-rata 93 dengan kualifikasi sangat baik (SB). Dapat disimpulkan bahwa siklus II sudah baik dan telah mencapai kriteria ketuntasan minimal 75 . Untuk itu tidak perlu diadakan tindakan lanjut dan penelitian dapat diakhiri pada siklus II ini. 
Tabel 2. Hasil Pengamatan RPP, Aspek Guru, Aspek Siswa Siklus II

\begin{tabular}{llcc}
\hline No & Hasil Pengamatan & Siklus II & Rata-rata \\
\hline 1. & RPP & 92,59 & 92,59 \\
2. & Aspek guru & 95,00 & 95,00 \\
3. & Aspek siswa & 95,00 & 95,00 \\
4. & Hasil belajar & 93 & 93 \\
\hline
\end{tabular}

\section{Refleksi}

Berdasarkan pengamatan pelaksanaan pembelajaran dari aktivitas guru, peserta didik pada siklus II telah terlaksana dengan baik dan hasil belajar peserta didik sudah meningkat. Dengan demikian, penelitian proses pembelajaran model Problem Based Learning berhasil dengan sangat baik sesuai dengan yang diharapkan. Rekapitulasi Peningkatan hasil belajar siswa dapat dilihat pada tabel 3 berikut.

Tabel 3. Rekapitulasi hasil Pengamatan RPP, Aspek Guru, Aspek Siswa Siklus I dan II

\begin{tabular}{llllc}
\multirow{2}{*}{ No } & \multirow{2}{*}{ Hasil Pengamatan } & \multicolumn{2}{c}{ Siklus } & \multirow{2}{*}{ Rata-rata } \\
\cline { 3 - 4 } & & \multicolumn{1}{c}{ I } & II & \\
\hline 1. & RPP & 81,48 & 92,59 & 87 \\
2. & Aspek guru & 82,50 & 95,00 & 89 \\
3. & Aspek siswa & 82,50 & 95,00 & 89 \\
4. & Hasil belajar & 78 & 93 & 86 \\
\hline
\end{tabular}

\section{SIMPULAN}

Berdasarkan hasil penilitian yang telah dilakukan di SD Negeri Ketanggan 02 maka diperoleh kesimpulan bahwa problem based learning dapat meningkatkan hasil belajar peserta didik. Dari paparan data dan hasil penelitian serta pembahasan yang dapat diambil dari penelitian ini adalah sebagai berikut:

Hasil penelitian menunjukkan bahwa penilaian RPP siklus I pertemuan I persentase yang diperoleh yaitu $77,78 \%$ dengan kualifikasi $\mathrm{B}$ dan kekurangan pada siklus I pertemuan I diperbaiki pada siklus I Pertemuan II sehingga siklus I pertemuan II memperoleh nilai persentase $85,19 \%$ dengan kualifikasi B dan semakin meningkat pada siklus II dimana penilaian RPP memperoleh hasil 92,59 \% dengan kualifikasi SB. Dari hal ini terlihat bahwa ada peningkatan dalam rencana pelaksanaan pembelajaran tematik menggunakan model problem based learning

Hasil pengamatan dari pelaksanaan pembelajaran dengan model problem based learning. Dapat diamati dari aktivitas guru dan aktivitas peserta didik. Aktivitas guru pada siklus I pertemuan I menunjukan bahwa pelaksanaan pembelajaran memperoleh persentase $80,00 \%$ dikualifikasikan cukup (B), aspek peserta didik sebesar $80,00 \%$ dikualifikasikan cukup (B). Pada siklus I pertemuan II penilaian terhadap aspek guru adalah 85,00\% dikualifikasikan baik (B) dan aspek peserta didik sebesar 85,00\% dikualifikasikan baik (B). Pada siklus II nilai persentase rata-rata aspek guru adalah 95,00\% dikualifikasikan sangat baik (SB), aspek peserta didik adalah 95,00\% dikualifikasikan sangat baik (SB). Dari hal ini terlihat bahwa ada peningkatan terhadap pelaksaan pembelajaran menggunakan model Problem Based Learning baik dari aspek guru maupun aspek peserta didik.

Hasil belajar peserta didik dengan menggunakan model Problem Based Learning juga meningkat. Pada siklus I pertemuan 1 memperoleh rata-rata kelas 74 , siklus I pertemuan II memperoleh rata-rata kelas 82 dan siklus II memperoleh rata-rata kelas 93. Hal ini membuktikan bahwa pelaksanaan penelitian yang telah dilakukan di SD 
Negeri Ketanggan 02 dengan menggunakan model Problem Based Learning (PBL) telah berhasil.

\section{DAFTAR PUSTAKA}

Anggarayanthi, L. A., Suniasih, N. W., \& Suara, I. M. (2016). Penerapan Model Discovery Learning Berbantuan Media Llingkungan untuk Meningkatkan Hasil Belajar IPA Tema Ekosistem Siswa Kelas VA SD N 12 Padang Sambian. eJournal Universitas Pendidikan Ganesha, 4 (1), 2.

Anugraheni, I. (2017). Penggunaan Portofolio dalam Perkuliahan Penilaian Pembelajaran. Jurnal Pendidikan Dasar PerKhasa, 3(1), 248.

Arikunto, Suharsimi, dkk. (2015). Penelitian Tindakan Kelas Edisi Revisi. Jakarta : Bumi Aksara.

Kemendikbud, (2014). Materi Pelatihan Guru Implementasi Kurikulum 2013 Tahun 2014 SD Kelas IV. Jakarta: Pusat Pengembangan Sumber Daya Manusia Pendidikan Kebudayaan dan Penjaminan Mutu Pendidikan.

Majid, Abdul. (2014). Pembelajaran Tematik Terpadu. Bandung: PT Remaja Rosdakarya.

Marsali, Annisa. (2016). Peningkatan Pembelajaran Tematik Terpadu Dengan Menggunakan Model Problem Based Learning Di Kelas IV Sekolah Dasar. Jurnal Inovasi Pembelajaran SD, XII(1), 98-100.

Miaz, Yalvema. (2015). Penelitian Tindakan Kelas Bagi Guru dan Dosen. Padang: UNP Press Padang.

Mustamilah.(2015). Peningkatan Keterampilan Proses dan Hasil Belajar Menggunakan Model Problem Based Learning pada Sub Tema Merawat Tubuhku Siswa Kelas 1 SD Negeri 1 Gosono - Wonosegoro. 5(1).

Sani, R,A. (2019). Strategi Belajar Mengajar. Depok: Rajawali Pers.

Trianto. (2014). Model Pembelajaran Terpadu. Jakarta: PT Bumi Aksara.

Trianto. (2015). Model Pembelajaran Terpadu. Jakarta: PT Bumi Aksara. 